\title{
Pawang Ternalem Drama Text as a Material Indonesian Language in Grade VIII of Junior High School
}

\author{
Egitamersa Yolanda Br Bangun ${ }^{1}$, Rosliani $^{2}$ \\ ${ }_{1}^{1}$ Universitas Prima Indonesia, Indonesia \\ 2Pusat Bahasa Sumatera Utara, Indonesia \\ Email: egita_bangun@yahoo.co.id; rosliani.12@gmail.com
}

\begin{abstract}
This study aims to determine the intrinsic elements and the value of character education in the Pawang Ternalem drama script, as well as to determine the benefits of the analysis of drama scripts as teaching materials for Indonesian in Grade VIII. This study uses qualitative methods with data analysis techniques used are descriptive analysis. Based on the results of data processing, the research results show that in the Pawang Ternalem drama script there are intrinsic elements including themes, characters and characterizations, plot, setting, language style in dialogue, and mandate. In addition to the intrinsic elements of the drama script, 10 character education values were found, namely the values of religious character education, honesty, tolerance, hard work, creative, independent, respect for achievement, friendly / communicative, social care, and responsibility.
\end{abstract}

Keywords: Pawang Ternalem drama script; teaching materials; Indonesian language

\section{Introduction}

Teaching Indonesian language in formal education is not only about the Indonesian language but also the learning process in the classroom that gives students the ability and skills to appreciate literature through a process that relates to producing literary works with what students learn. Literature as a reflection of the socio-cultural conditions of the nation must be passed on to its young generation (Wiwita, 2020). School is an institution for formal learning and teaching which is expected to be able to provide guidance and development for teaching language and literature for students. The main target in teaching literature, especially drama, is school because school is a place or place to instill life values that are not only looking for meaning but also giving meaning to literary works created by the writers concerned. Hence, his insistence that concepts both 'literature' and 'criticism' were forms of a class specialization and control of a general social practice, and of a class limitation of the question" (Williams in Gaeini, 2019).

Atmazaki in his book Theory and Applied Literature (1990: 31) explains that what determines a literary work is called drama, namely dialogue. Literary works of drama are full of dialogue between characters that occurs between more than two characters. In line with Atmazaki's opinion, Sumardjo and Saini in their book Appreciation of Literature (1997: 31) also agree that drama is a literary work whose stories are expressed by dialogue between characters but as literary works, drama is only temporary because drama scripts are written as a basis for staging. In junior high school education, the curriculum used is the 2013 curriculum in which there are basic competencies that become the competency standards of students in understanding the elements of drama in the form of performances or scripts, to be precise in Basic Competence 3.15 Identifying the elements of drama (traditional and modern) presented in the form of a stage or a script. Through this learning, students are expected to be able to understand the elements contained in a drama script, especially the intrinsic elements of a drama script. 
Based on the author's observations are of the grade VIII Indonesian student handbook, which in the book only includes modern drama scripts. Modern and traditional drama scripts have differences, for example in language style and diction. In this study, the writer offers a traditional drama script as teaching material, namely the Pawang Ternalem drama script. The writer chose the drama script because the story of Pawang Ternalem originated from Karo Land, North Sumatra. In addition, the drama script Pawang Ternalem is also one of the oral literary works that deserves to be preserved.

According to Wiyanto in his book Skilled in Drama (in Bangun, 2018: 9) etymologically the word drama comes from the Greek word dram which means "movement" and draomai which means "to do, to act, or to act" (Kosasih, 2017: 240). In contrast to Wiyanto's opinion, Ahmadi (in Endraswara, 2011: 11) said that drama comes from the Greek (Ancient Greek) drau which means doing (action) or doing something. Drama is an imitation of human life that is projected on the stage. Kosasih (2017:240) argues that drama is a form of literary work that aims to describe life by conveying contention and emotions through actions and dialogue. Actions and dialogue in drama are not much different from actions and dialogues in everyday life. A drama cannot be separated from a drama script. Drama scripts are essays containing stories or plays (Wiyanto in Bangun, 2018: 10). According to Endraswara (2011: 37) a drama script is a work of fiction that has a unity of text and contains a story or play. In the drama script, it is also written how each character expresses his dialogue, whether in a loud, weak or whispered voice.

In a literary work there are elements of its builder. Drama script is built by two important elements, namely intrinsic elements and extrinsic elements. However, this research focuses on the intrinsic elements of a drama script which includes themes, characters and characterizations, plot, setting, language style in dialogue, and mandate (Kemal in Bangun, 2018: 11). In addition to the intrinsic elements of the drama script, this study also analyzes the value of character education contained in the drama script. Character education is placed as the foundation for realizing the vision of national development, namely realizing a society with noble, moral, ethical, cultured, and civilized characters based on the philosophy of Pancasila (Hartono, 2014: 262). The values developed in character education in education units in Indonesia are identified from religion, Pancasila, culture, and national education goals. Based on these four sources, 18 values of character education were identified, namely religious, honest, tolerance, discipline, hard work, creative, independent, democratic, curiosity, national spirit, love for the country, respect for achievement, friendly / communicative, peace-loving, likes reading, cares about the environment, cares about social, and is responsible.

After analyzing the intrinsic elements and the value of character education in the Pawang Ternalem drama script, the benefits of the analysis results as teaching materials will be presented. According to KTSP (Yuliastanti, 2013: 22) teaching materials are a component of a learning system that plays an important role in helping students achieve competency standards and basic competencies. Therefore, it is necessary to develop effective teaching materials to support the learning process. From this opinion it can be concluded that teaching materials are a set of materials designed to assist teachers in the teaching-learning process so that students can achieve the goals of competency standards and also basic competencies. From this explanation, the Pawang Ternalem drama script can be analyzed the intrinsic elements and the value of character education, and find the benefits of the results of this analysis as Indonesian language teaching materials in grade VIII of Junior High School. 


\section{Research Methods}

The research method has an important role in a study. The success of a person in conducting a study will be determined by the method used by the researcher. This study used qualitative research methods. A qualitative research method is a research that produces descriptive data on written and spoken words from people whose behavior can be observed (Bogdan and Taylor in Moleong, 2005: 4).

Data collection techniques are an important job in this research step. The data collection technique used is the type of literature study data collection. Literature study can be interpreted as a step to obtain information from previous research that must be done, regardless of whether the research uses field or laboratory research or in a museum. Library sources can be obtained from books, journals, magazines, research results (thesis or dissertation), and other relevant sources. In this research, the library sources were obtained from an electronic written letter (internet) in the form of the story of Pawang Ternalem which was later converted into a drama script. From this technique, research data obtained in the form of words and sentences as data sourced from the drama Pawang Ternalem.

The data analysis technique used is descriptive data analysis, namely data analysis used to analyze data by describing the data that has been collected as it is without intending to make conclusions that apply to the public (Sugiyono, 2016: 147).

Descriptive data analysis was used to describe the intrinsic elements and value of character education contained in the Pawang Ternalem drama script and the benefits of the drama script as Indonesian language teaching materials in grade VIII of Junior High School.

\section{Discussion}

Karo Land is a district in the province of North Sumatra, which is located in the Karo highlands. As one of the ethnic groups in Indonesia, Karo Land has natural charm, uniqueness, characteristics, literary works, and culture that are no less interesting than other tribes. Karo Land is inhabited by Karo people, most of who work as farmers. The fertile nature makes Karo Land an area known for its produce such as vegetables and fruits. As a district, Karo Regency has its own language which is different from other Batak languages which is called Karo Language. There are so many literary works from Karo Land, but due to the times and the lack of curiosity in oneself, these literary works are almost forgotten. Literary works originating from Karo Land such as anding-andingen, kuning-kuningen, ndung-ndungen, tabas, and folk tales.

Pawang Ternalem is a folk tale originating from Karo Land, to be precise the village of Liang Melas which was founded by Merga Sembiring Kembaren. The birth of Ternalem is believed to be the cause of the death of both of his parents. On the orders of Guru Sibaso, Ternalem was then dumped in the forest. After growing up to be a young man, he then met Datuk Rubia Gande from Batang Serangan village. Ternalem told the story of his life so that Datuk Rubia Gande was interested and then invited Ternalem to come with him to Batang Serangan.

Teralem is a given name from Datuk Rubia Gande because only he is able to conquer Tualang Si Mande Angin and take honey from the tree to treat Beru Patimar. The story of Pawang Ternalem was rewritten by Joey Bangun based on observations and research in Jenggi Kemawar in 2007. 
below.

The discussion about the results of the analysis of the drama script will be explained

\subsection{Intrinsic Elements in Pawang Ternalem Drama Script}

The results of the analysis of the intrinsic elements contained in the drama script will be described below.

\subsection{Theme}

A theme is an idea / idea / story basis in writing a literary work and cannot be understood if you do not understand the whole story. Based on the classification of themes according to Waluyo (2011: 8), the theme of the drama script Pawang Ternalem is a physical one. Physical themes concern the core of the story relating to human physical needs, one of which is the struggle for life.

The drama script tells about the life struggle of Pawang Ternalem who from birth was called the unlucky child until he finally married the daughter of Pengulu Jenggi Kemawar, named Beru Patimar. This theme is implicit in every dialogue between characters, so one must understand the whole story in order to find the theme in the drama script.

\section{a. Character and Characterizations}

Character and character are closely related. The characters in the drama act to bring the story to life in the drama script. Characters are people who play a role in drama and characterizations are the characters or characteristics of each character. In the Pawang Ternalem drama script, there are twelve characters with different characters. The characters and characterizations in the drama script will be described below.

\section{Pawang Ternalem}

Based on the drama script, Pawang Ternalem is a young man who is handsome, dashing, kind, obedient, persistent, does not regret his life, and is confident. This can be seen in the following quote.

"...Then Pawang Ternalem is together with Dara's family. He looks manly and handsome. People were shocked to see the changes especially Beru Patimar."

Pengulu Jenggi Kemawar: "I am sorry for Beru Patimar's behavior towards you"

Pawang Ternalem : "That's not a problem for me. I just want to beal Beru Patimar. I ask permission to beal him .....

Pawang Ternalem : (before going upstairs) 'Father, Nande, I don't regret being born alone like this. Even though, it is full of misery and suffering but tonight, I ask you one request, allow me to have an honor."

\section{Guru Sibaho}

The character of Guru Sibaso in the drama script is someone who is angry and the role of Guru Sibaso is an antagonistic role. This can be seen in the following quote..

Guru Sibaso: "If you raise the emperor's delayed child then you will be expelled from this village ..."

Guru Sibaso : (approached Ternalem and with an angry tone) " Get out from here! This is all your faults! You are the unlucky bearer who caused our village to never progress. Apparently there are you, the unlucky child who is present among us."

3. Menda

Menda is Pawang Ternalem's aunt who is obedient. This can be seen in the following quote. 
"Without arguing and with fear, Menda cried and carried her candy towards the village border. When he got there, Menda put the baby down ..."

\section{Perlanja Sira}

In the drama script Pawang Ternalem, the character Perlanja Sira has a prejudice against others. This can be seen in the following quote..

Perlanja sira: "I was suspicious of the young man and I have heard who he really is. That young man's presence is a burden for us."

\section{Datuk Rubia Gande}

Datuk Rubia Gande is told as a kind person who cares for others. This can be seen in the following quote.

"Datuk Rubia Gande was interested in the story of Pawang Ternalem and immediately took his hand and read the hand lines of Pawang Ternalem. Then he invited the Pawang Ternalem to come with him."

Datuk Rubia Gande: "I have given the magicpower of a handler, you have to go there Kempuku, Ternalem. You have to prove that the knowledge I gave you was not in vain. You have to take honey from Tualang Si Mande Angin and treat Beru Patimar. That girl must be treated my son."

6. Tulang Kelambir Gading

Datuk Rubia Gande has a daughter named Tulang Kelambir Gading. Gading Kelambir bones have good qualities and do not like pride. This can be seen in the following quote.

Tulang Kelambir Gading: (while following his Father) "I do not like the arrogance of the daughter of Pengulu Jenggi Kemawar, Father. He must feel the consequences of his actions."

\section{Dara}

Dara is a messenger from the Kuta Jenggi Kemawar who has a good character. This can be seen in the following quote.

Dara : (defend Ternalem) "He iss not a Begu, Beru Patimar. He is a handler who will conquer Tualang Si Mande Angin"

Pawang Ternalem : "Take it easy, I will be fine."

Dara : (Khawatir) "I told you, you can not climb it."

8. Pengulu Jenggi Kemawar

Pengulu Jenggi Kemawar has the character of a leader who is firm, kind, and keeps his promises. This can be seen in the following quote.

Pengulu Jenggi Kemawar: "According to the promise I made in the competition throughout Karo Land, Deli, and Langkat that anyone who can take the honey and heal my daughter has the right to be the behavior. As a pengulu, I will keep my promise."

9. Dayang I

Dayang I had an unyielding nature in entertaining the daughter of Pengulu Jenggi Kemawar. This can be seen in the following quote.

Dayang I : (Entertain) "We always hope that someday there will be a handler who will succeed in climbing the Tualang Si Mande Angin"

10. Royal Advisor

The Royal Counselor has a character of doing his job well. This can be seen in the following quote. 
Royal Counselor: "Last night the teacher had a vision from his dream that soon a handler would take the honey. He managed to climb the tree even he was already in Pengulu Jenggi Kemawar.”

\section{Beru Patimar}

Beru Patimar is the daughter of Pengulu Jenggi Kemawar who has a beautiful face but is arrogant and stubborn. This can be seen in the following quote.

Pawang Ternalem : "She is very beautiful girl"

Tulang Kelambir Gading: (while following his Father) "I do not like the arrogance of the daughter of Pengulu Jenggi Kemawar, Father. He must feel the consequences of his actions."

Beru Patimar : : (shocked and angry) "Why did you introduce Begu to me, Dara?"

\section{Nondong}

In its role, nondong has an unyielding and forgiving nature. This can be seen in the following quote.

Nondong: "Beru Patimar o Beru Patimar, the message rang again. I am sure this time you heard it. I will prove if what I said is true."

\section{b. Plot}

Plot is the process of the course of a story. The progression is a series of events from the beginning to the end of the story. The plot in the drama script uses a forward plot because it tells the story of Pawang Ternalem starting from his birth which causes him to be nicknamed the delayed son of kais (unlucky bearer) because his birth is precisely the cause of the death of his parents, Pawang Ternalem's life journey in the forest, meeting with Datuk Rubia Gande, conquering Tualang Si Mande Angin, until finally he married the daughter of Pengulu Jenggi Kemawar, Beru Patimar.

\section{c. Setting}

Setting is a description of the place, time and atmosphere of the character's actions or events experienced by the character. According to Pratiwi and Siswiyanti (2016: 86), the setting is manifested in three forms, namely the setting of the place, the setting of time, and the setting of the atmosphere. These three backgrounds are contained in the drama script Pawang Ternalem which will be described below.

\section{Place Setting}

The setting place where the events or events occur, featuring the characters. The setting in the Pawang Ternalem drama script is Liang Melas village, village border, the middle of the forest, Karo traditional house, sapo, Jenggi Kemawar village, Beru Patimar's terrace house, Pengulu Jenggi Kemawar house, and Batang Serangan.

\section{Time Setting}

Time setting is a description of the time when the events or events in the story occurred. The time setting contained in the drama script Pawang Ternalem is evening and evening. The time setting is shown in the following quote.

"The warm welcome of the Datuk Rubia Gande family made Pawang Ternalem comfortable there. During dinner, there was the sound of hammering drums that were getting closer and closer. She is the Dara with the name Revolusi-Angin bebere Ginting from the village of Jenggi, Kemawar".

"For months, Datuk Rubia Gande taught magic skills to Pawang Ternalem including pawang knowledge. One afternoon in a sapo not far from his house, Datuk. Rubia Gande invited Pawang Ternalem to talk". 


\section{Situation Setting}

The atmosphere setting relates to the atmosphere that is built in a story. The setting of the atmosphere in the Pawang Ternalem drama script is sad, happy, and tense. The setting of the atmosphere in the drama script is shown in the following quote.

"Without arguing and with fear Menda cried and carried her candy towards the village border. When he got there Menda put the baby down. Several years later, the abandoned baby grew up to be a sad child and he saw his aunt Menda and called out to her..."

"Pawang Ternalem comes down from the tree and has brought the honey and has put the honey into the kitang. Dara welcomed him happily".

"In the evening, Pawang Ternalem and Dara came to Tualang Simande Angin. The tree was scary and Dara was getting nervous."

\section{d. Language Style in Dialogue}

Language style in dialogue is a beauty created by the author's ability to choose words and language styles in character dialogue in a drama script. The language style in the dialogue contained in the drama script uses figures of speech and terms from the Karo regional language. The use of figure of speech will be described in the following.

\section{The Use of Speech Figure}

In the drama script, sarcasm and metaphor are used. Sarcasm is a reference that contains bitterness and bitter reproach (Keraf, 2006: 143). Sarcasm can be ironic or not, but it is always offensive and unpleasant to hear. The use of sarcasm is shown in the following quote.

Beru Patimar : (shocked and angry) "Why did you introduce me to Dara?"

Dara : (defend to Pawang Ternalem)" He is not Begu, Beru Patimar. He is a handler who will conquer Tualang Si Mande Angin."

Beru Patimar : (angry) "Never mind, I don't care about bim. I just want to be introduced to bumans not like that."

Meanwhile, metaphorical figure is a kind of analogy that compares two things directly, but in a short form (Keraf, 2006: 139). The use of metaphorical figures in the drama script is shown in the following quote.

Beru Patimar : : (shocked) "Why can everything change?"

Pawang Ternalem : (smile) "Hatindu who can change me like this, Nande Karo."

\section{The Use of Karo Regional Language Terms}

The drama script Pawang Ternalem is a literary work originating from Karo Land so that in writing the drama script uses terms commonly used by the Karo people when talking to their interlocutors. The terms of the Karo regional language contained in the drama script are as follows.

- Bibi is the name for a father or mother's sister.

- Kais delay is a term for a child whose birth brings disaster to their parents or family, also known as unlucky bearers.

- Permen is a term for a niece or daughter-in-law.

- Perana child is the term for unmarried youth

- Kam is a singular and plural second person pronoun used of a person who is respected or older.

- $\quad-n d u \neg$ is your clit or you.

- Surdam is a wind instrument made of bamboo.

- Percibalen is a place of sacrifice. 
- Father and nande are the names for parents, father or mother.

- Parrots are songs that contain lamentation.

- Merga and bebere. In the karo community known as merga which is obtained from the father's line. The content of merga is used by men, while for women it is called beru. Bebere or bere-bere is a merga of someone drawn from their mother's beru.

- Speech is a kinship or kinship between two individuals, the level of one's calling to someone.

- Headdress is the name for grandfather.

- Pengulu is the name for the village head or village head.

- A teacher is a shaman, a smart person, a person who is good at fortune-telling, a person who can relate to spirits, an expert in traditional medicine.

- Malem is a condition of someone who has recovered and is no longer sick.

- Sapo is a hut, small house, or hut.

- Kempu is a call for grandchildren.

- Mbayu is an activity of weaving, knitting, making baskets, mats, and so on.

- Kela is the name for a son-in-law.

- Begu is the spirit of a person who has died.

- Kuta is a village or village.

- Mejuah-juah is the greeting of the karo people which means being in good health, in a happy state, in good condition.

- Kemberahen is a polite expression for addressing wife.

- Perbulangen is a polite expression for addressing husband.

- Senina is sibling, family ties between men and women or women and women.

- Taneh is land or area.

- Longitude is an expression of gratitude used by the Karo community.

- Kesain is the yard of a house, village field, square, a clean environment of a village.

- Nande karo is a call to a woman based on her beru.

- Kitang is a container for sap made of bamboo so that it can be poured directly into the mouth.

\section{e. Mandate}

Mandate is a moral message conveyed by the writer to the script reader or drama audience through the literary work he has created. The mandate of the Pawang Ternalem drama script is never to underestimate a person only because of his physical or life story because we don't know what happens to him the next day.

\section{f. The Value of Character Education in the Pawang Ternale m Drama Script}

After analyzing the intrinsic elements in the Pawang Ternalem drama script, the next step is to find the value of character education contained in the drama script. Of the 18 values of character education, there are 10 values of character education in the drama script Pawang Ternalem, namely:

\section{Religious}

The value of religious character education is characterized by obedient attitudes and behavior in carrying out the teachings of the religion they adhere to, being tolerant of the implementation of the worship of other religions, and living in harmony with adherents of 
other religions. The religious value in the drama script is when Guru Sibaso believes that the birth of Pawang Ternalem is an unlucky bearer because it caused his parents to die. With the existence of religious values, it is expected to be able to guide students to be more confident in their beliefs and tolerant of other people's beliefs.

\section{Honestly}

The value of honest character education is characterized by behavior that is based on an effort to make himself a person who can always be trusted in words, actions, or work. The value of honesty in the drama script is when Menda honestly reveals that she was not the one who raised Pawang Ternalem. With the value of honesty it is hoped that it can help students to behave honestly.

\section{Tolerance}

The value of tolerance character education is indicated by attitudes and actions that respect differences in religion, ethnicity, opinion, attitudes and actions of others who are different from them. The value of tolerance in the drama script is when Dara admits that Ternalem is her brother even though Dara and Ternalem have no family relationship. With the value of tolerance, it is hoped that teachers will be able to guide students to appreciate differences.

\section{Hard Work}

The value of hard work character education is shown by a behavioral attitude that shows serious efforts in overcoming various learning and assignment obstacles, and completing tasks as well as possible. The value of hard work in the drama script is when Pawang Ternalem still tries to convince Dara that he is able to conquer Tualang Si Mande Angin. With the value of hard work, it is taught that success will not be achieved without going through a winding process.

\section{Creative}

The value of creative character education is shown by the attitude of thinking and doing something to produce new ways or results from something that is already owned. The creative value in the drama script is when Pawang Ternalem makes surdam from bamboo. With this value, it is hoped that students and teachers will foster a creative attitude within themselves.

\section{Independent}

The value of independent character education is shown by attitudes and behaviors that are not easily dependent on others to complete tasks. The independent value in the drama script is when Pawang Ternalem is thrown into the forest but still survives. With this value, students are required to be able to be independent and not depend on anyone.

\section{Rewarding Achievements}

The value of character education respecting achievement is shown by attitudes and actions that encourage him to produce something useful for society, and recognize and respect the success of others. The value of appreciating the achievement in the drama script is when the Pawang Ternalem can conquer Tualang Si Mande Angin and bring honey to treat Beru Patimar, and then Dara happily welcomes and compliments him for having succeeded in bringing the honey. With this value, it is hoped that students can appreciate the achievements made by their friends and make it a motivation for themselves instead. 


\section{Friendly / Communicative}

The value of friendly / communicative character education is shown by actions that show a sense of pleasure in talking, associating, and working with others. Friendly / communicative value in the drama script can be seen when Dara welcomes Pawang Ternalem at Jenggi Kemawar and introduces that Ternalem is her art, even though they are not in a family relationship. With this value, students are expected to be able to get along with their friends regardless of differences in religious, ethnic, and racial backgrounds. Teachers are also expected to be able to establish good relationships with other teachers and provide students with understanding that differences are beautiful.

\section{Social Care}

The value of social caring character education is shown by the attitude and actions that always want to provide assistance to other people and communities in need. The value of social care in the text is when Datuk Rubia Gande and his daughter Tulang Kelambir Gading helped Pawang Ternalem to heal the wounds suffered by Beru Patimar. The value of social care invites students to instill a sense of sympathy for others.

\section{Responsible}

The value of responsible character education is marked by the attitude and behavior of a person to carry out his duties and obligations, which he should do to himself, society, the environment, the State, and God Almighty. The value of responsibility in the text is when the Pawang Ternalem gets an assignment from Datuk Rubia Gande to heal Beru Patimar's wounds. The value of responsibility requires teachers to guide students to be responsible for their duties or what is done.

\section{g. Benefits of Pawang Ternalem Drama Script Analysis Results as Teaching Materials}

Based on the results of the analysis of intrinsic elements and the value of character education in the Pawang Ternalem drama script, the drama script can be used to help understand drama learning material in junior high school. In accordance with the demands of the 2013 Curriculum at BC (Basic Competence) 3.15 to identify the elements of drama (traditional or modern) which are presented in the form of a stage or script, the Pawang Ternalem drama script can be used as teaching material in grade VIII of Junior High School. The intrinsic elements of a drama script include themes, characters and characterizations, plot, setting, style in dialogue, and message. These six elements are contained in the drama script Pawang Ternalem which has been described in the previous discussion.

The Pawang Ternalem drama script is a literary work that deserves to be preserved. The use of traditional drama scripts such as Pawang Ternalem as teaching materials can be a medium for introducing literary works from North Sumatra to students. With the use of this drama script, it is hoped that it can foster curiosity in students about literary works originating from North Sumatra.

According to the Center for Curriculum and Book of the Ministry of Education and Culture, there are 18 character educations as a reference for teaching materials. The use of the drama script as teaching material can teach the values of character education to students. In the Pawang Ternalem drama script there are several values of character education, such as religious, honest, tolerance, hard work, creative, independent, respect for achievement, friendly / communicative, social care, and responsibility. 


\section{Conclusion}

The drama script of Pawang Ternalem is one of the literary works originating from Karo Land, North Sumatra which deserves to be preserved. The use of regional literary works as teaching materials can introduce these literary works to students so that they can be slowly preserved. Drama scripts are built by intrinsic elements including themes, characters and characterizations, plot, setting, language style in dialogue, and message. The six intrinsic elements are contained in the drama script Pawang Ternalem.

A literary work is said to be used as teaching material if it contains character education values. In the Pawang Ternalem drama script, there are values of religious character education, honesty, tolerance, hard work, independence, creativity, respect for achievement, friendly / communicative, social care, and responsibility. The use of drama scripts is also useful for creating students' curiosity about literary works originating from North Sumatra.

\section{References}

Amanda, Widyasni dkk. 2017. Naskah Drama Aeng Karya Putu Wijaya dan Implikasinya. Jurnal Kata (Bahasa, Sastra, dan Pembelajarannya). 1-12

Anggraini, Tri Riya. 2016. Pengembangan Bahan Ajar Kajian Sastra. Prosiding Seminar Nasional Language Education and Literature (LANGEL) ke-1.Pengajaran Sastra Indonesia, Daerah, dan Asing”. Pascasarjana UNJ Jakarta: 26 Oktober 2016. 17-24

Arikunto,S. 2016. Prosedur Penelitian Suatu Pendekatan Praktik. Jakarta: Rineka Cipta.

Atmazaki.1990. Ilmu Sastra Teori dan Terapan. Padang: Angkasa Raya Padang.

Bangun, E. A. 2012. "Analisis Tuturan Kru Bus Jurusan Kabanjahe-Medan Tabun 2011 (Interaksi Antara Kru Bus-Penumpang/Calon Penumpang”.Skripsi FBS Unimed. Unimed Medan: tidak diterbitkan.

Bangun, E. Y. 2018. "Peningkatan Kemampuan Siswa dalam Menganalisis Unsur Intrinsik Naskah Drama Menggunakan Model Pembelajaran Kooperatif pada Siswa Kelas VIII-2 SMP Swasta Nurcahaya Medan T.P. 2017/2018”. Skripsi FKIP UNPRI. UNPRI Medan: tidak diterbitkan.

Dalman. 2014. Keterampilan Menulis. Jakarta: Rajawali Pers.

Departemen.Pendidikan Nasional. 2005. Kamus Besar Bahasa Indoneisa Edisi Ketiga. Jakarta: Balai Pustaka.

Endraswara, Suwardi. 2011. Metode Pembelajaran Drama (Apresiasi, Ekspresi, dan Pengkajian). Jakarta: PT Buku Seru.

Fahmi, Reza Nurul, dkk. 2014. Analisis Tokob Utama dan Nilai Pendidikan Karakter dalam Novel Anak Sejuta Bintang Karya Akmal Nasery Basral. 2(3). 1-11

Gaeini, M., Soqandi, M., and Basirizadeh, F.S. (2019). The Role of Language and its Analysis in James Joyce`s Dubliners within the Light of Cultural Materialism. Budapest International Research and Critics in Linguistics and Education (BirLE) Journal Vol 2 (2): 16-26.

Hartanto.2014. Pendidikan Karakter dalam Kurikulum 2013. Jurnal Budaya. 19(2). 259-268

Isnaeni, Lidya Putri. 2017. "Analisis Kemampuan Siswa dalam Mengidentifikasi Informasi Teks Eksposisi Berorientasi Struktur dan Isi pada Siswa Kelas VII SMP Muslimin 3 Bandung Tahun Pelajaran 2016/2017. Skripsi FKIP UNPAS. UNPAS Bandung

Keraf, Gorys. 2006. Diksi dan Gaya Bahasa. Jakarta: PT Gramedia Pustaka Utama

Kosasih. E. 2017. Ketatabahasaan dan Kesusastaan Cermat Berbahasa Indonesia. Bandung: CV Yrama Widya.

Moleong. L. J. 2005. Metodologi Penelitian Kualitatif Edisi Revisi. Bandung: PT Remaja Rosdakarya. 
Niarti, Novi. 2017. "Pengembangan Bahan Ajar Berbasis Multimedia Interaktifpada Materi Menyimak untuk. Siswa Kelas VI Sekolah Dasar”. Tesis FKIP Unila. Unila Bandar Lampung

Pratiwi.Y dan Frida S. 2014. Teori Drama dan Pembelajarannya. Yogyakarta: Ombak.

Sugiyono. 2016. Metode Penelitian Kuantitatif, Kualitatif, dan R\&D. Bandung: Alfabeta.

Sumardjo, S. dan Saini K.M. 1997. Apresiasi Kesusastraan. Jakarta: PT Gramedia Pustaka Utama.

Surya, Arie. 2018. Kemampuan Menganalisis Unsur Intrinsik Cerita Rakyat "Pawang Ternalem" oleh Siswa Kelas X SMA Negeri 1 Binjai Tabun Pembelajaran 2017/208. Skripsi FBS UNIMED. UNIMED Medan

Waluyo, H.J. 2011.Pengkajian dan Apresiasi Prosa Fiksi. Surakarta: UNS Press.

Widyahening, Evi Tri dkk. 2018. Kajian Drama: Teori \& Implementasi dengan Metode Sosiodrama. Surakarta: Cakrawala Media.

Wiwita, L., Marice, and Hadi, W. (2020). Validation of Experts to the Module Writing Short Text Based on Character Education in Class XI Students of SMA Negeri 1 Pangkalan Susu. Britain International of Linguistics, Arts and Education(BIoLAE) Journal Vol. 2 (1): 422-435.

Wiyanto, A. 2007.Terampil Bermain Drama. Jakarta: PT Grasindo.

Yuliastanti. 2013. "Pengembangan Bahan Ajar Membaca Sastra Berbasis Pendekatan Kontekstual pada Siswa Kelas VIII SMP Kota Yogyakarta”. Skripsi FBS UNY. UNY Yogyakarta

Zebua, T. 2016. "Upaya Meningkatkan Kemampuan Menganalisis Unsur Intrinsik Cerita Rakyat Nias melalui Metode Kontekstual oleh Siswa Kelas VII Natrium SMP Global Prima National Plus Medan Tahun Pelajaran 2015-2016”. Skripsi FKIP UNPRI. UNPRI Medan: tidak diterbitkan. 